\title{
BILL RICHARDS: IN LOVING MEMORY
}

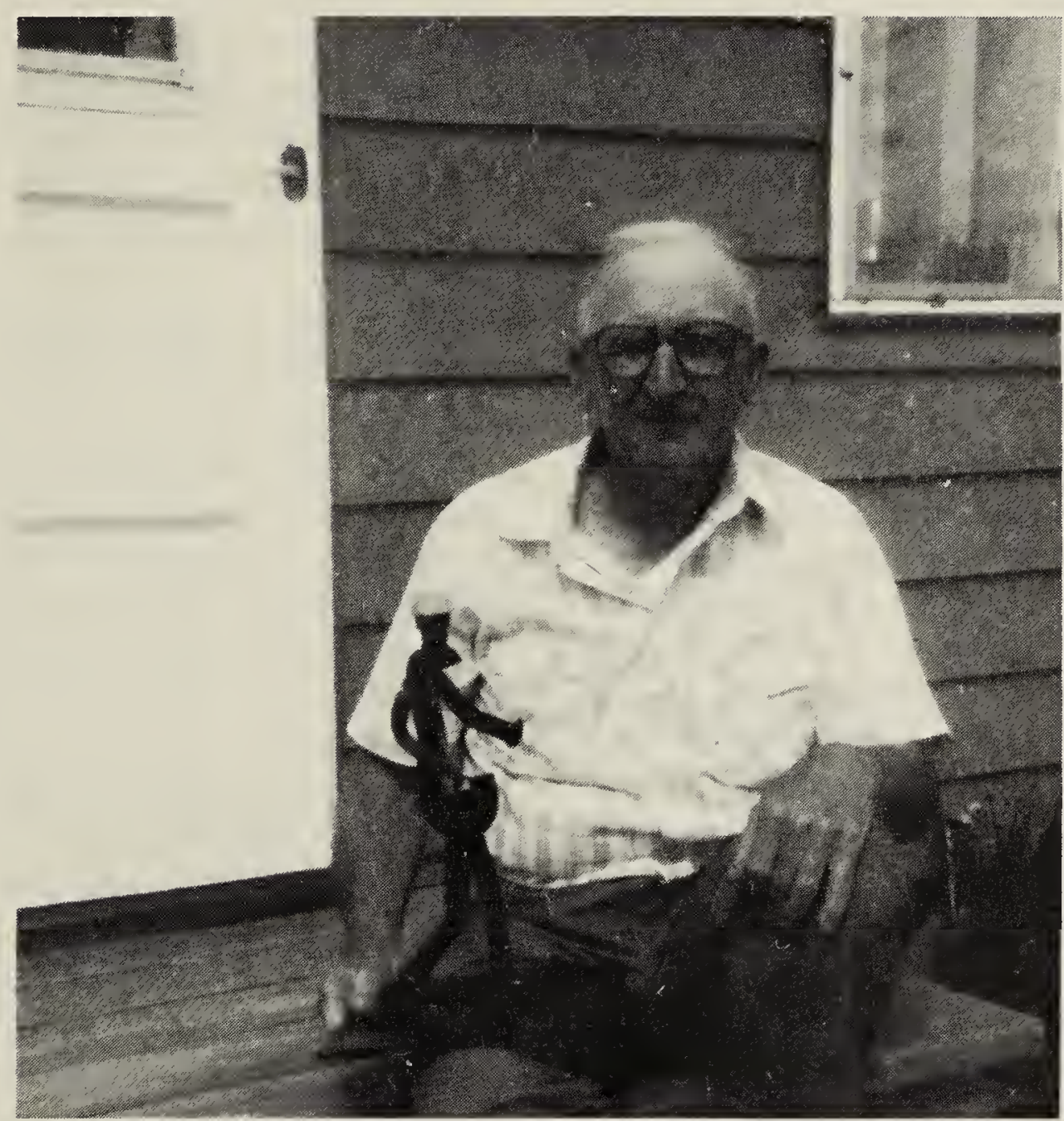

Bill Richards

Bill Richards loved Saskatchewan, this often harsh land to which he and his family emigrated from South Wales when he was eight years old. Except for a few years just before and during World War II, he lived his entire adult life here. Most of that time he worked outdoors, first on the farm, later as a "maintenance of way man" for the CNR. He could say feelingly with Robert Service, "Talk of your cold! through the parkas's fold it stabbed like a driven nail;" and he knew the fierceness of the prairie winds and the scorching heat of summer. But he preferred to contemplate the other side of Saskatchewan: miles of grass and wheat billowing in the wind; the play of light and shadow on the hills; the sudden burst of spring; the multitude of wild things - plants, birds, animals; the wooded banks of the Saskatchewan River, a riot of September gold.

Whenever Bill and Florence had a free day, they headed out in their car, a bountiful lunch and thermoses of good hot tea in a picnic hamper, ready to explore yet another road, cross another ferry, search for another Ferruginous Hawk nest. And very often they were part of a larger group, the Saskatoon Archaeological Society, the Saskatoon or the Saskatchewan Natural History Societies, or more recently the Golden Eagles, that happy fraternity of retirees who, rain or shine, spend every Thursday afield, often in these past two years with Bill as their leader. 
I think that one could honestly say of Bill that the last decades of his life were the happiest and most creative. One could summarize his life story simply by saying that he grew from strength to strength. Reaching manhood during the Great Depression, Bill had to leave Abermure rural school after completing his Grade 10. In the years before the war, like so many other young Canadians, he rode the freights, picking up jobs whenever and wherever he could. He worked on farms and in a store in southern Ontario.

When the war broke out, Bill wanted to join the Army, but despite repeated attempts to get into the Postal Corps, he was refused on the grounds that he had a bad eye. He subsequently trained as a mechanic, and in Montreal he found work in a propellor factory. There he met Florence Tibbits, a girl from Quebec's Eastern Townships. They were married in 1943.

After the war, Florence and Bill returned to the West and Bill began his career with the CNR. They lived for the first ten years in Wiseton and Dinsmore where theır two girls Gail and Fern were born.

In 1956 the Richards moved to Saskatoon, a move that profoundly changed their lives. Bill became an active member of several organizations (natural history, archaeology, stamp collectors), and continued to develop a wide range of hobbies that included the collection of postmarks, old postcards, stamps, and Indian artifacts; photography; botany; birdwatching; gardening; Saskatchewan history; and, most recently, collecting, identifying and mounting butterflies and moths. Yet despite the range of his interests, Bill was no mere dilettante. His knowledge of the postal history of Saskatchewan, for instance, was unsurpassed. Almost unfailingly he could identify any weed or flower brought to his attention, and when he couldn't he was humble enough to contact his good friend, botanist John Hudson, who would settle the matter. He read widely in the history of the Saskatchewan Indian and his impressive collection of arrowheads, scrapers, and other artifacts attests both to his keen eye and his knowledge of the time and places where he would most likely make finds.

By nature a rather shy, self-effacing man, Bill developed a host of friends, drawn to him by his wit, wisdom, and modesty. I doubt whether he ever fully realized how gifted he was. He had an amazingly retentive memory; you couldn't lose him anywhere in central Saskatchewan; he never forgot a trail, or a road, or a farmstead, even a culvert. He could stand on a promontory in the Coteau Hills south of Elrose; in the Thickwood Hills west of Prince Albert; or in his beloved Eagle Hills south of North Battleford ... and tell all of us, grouped around him, the names of the distant villages on the horizon, together with the date of their founding, their ethnic mix, and any other information we' $d$ care to ask! Bill loved books and enjoyed good music; he had an excellent singing voice, the product of his Welsh ancestry, no doubt. A great raconteur, he had a gift for imitating accents as he regaled his listeners with stories from his days on the farm and with the railroad. Florence and the girls remember him as a kindly, concerned father, a devoted husband, a family man proud of his six grandchildren, all boys.

Bill's health failed in recent years, but stoic that he was, he never complained. Carrying out his doctor's orders unquestioningly, he continued until this past week to get out into the country as often as he could, to bowl, and to pursue his many hobbies. The memory of Bill Richards is etched indelibly in the minds of those who knew and loved him. - J. Frank Roy, 1702 Sommerfeld Avenue, Saskatoon, Saskatchewan. S7H 2S8 